\title{
糸球体機能と腎予備能
}

\author{
山梨医科大学泌尿器科学教室（主任：上野 精教授） \\ 上 野 精 多 胡 紀一郎
}

\section{GLOMERULAR FUNCTION AND RENAL FUNCTIONAL RESERVE}

\author{
Akira Ueno and Kiichiro Tago \\ Department of Urology, Yamanashi Medical College, Yamanashi Japan \\ (Director: Prof. Akira Ueno)
}

\begin{abstract}
Protein intake has been shown to raise glomerular filtration rate (GFR). The difference between peak and baseline GFR following acute protein load indicates renal functional reserve (RFR). In this paper, we review 1) normal glomerular function and its regulating factors, 2) the concept of RFR and the mechanism by which the acute protein load induces hyperfiltration response in healthy subjects and 3) the RFR in patients with renal disease.
\end{abstract}

Key words: acute protein load, renal functional reserve, glomerular hyperfiltration

I.はじめに

毎日体内に取り入れられる水や電解質は，通常まず 細胞外液に入り, 細胞外液の量やそのイオン組成に影 響を及ぼす。しかし，その変動の範囲は狭く，体液量 やイオン組成はほぼ一定している，汗や呼吸などの不 感蒸泄による排出は, 定常状態では限られているので, 腎藏は水やイオンの排出経路の調節系として, 体内の 恒常性を保持する上で重要である。腎臓の機能は水, 電解質調節から酸一塩基平衡, ホルモン産生まで多岐 にわたり, 他の器官と協同して, 時には腎臓単独で, 休むことなく働いている。この腎臓の機能は, 主とし て糸球体と尿細管とによって維持されているわけだ が, 系球体機能に関しては, 泌尿器科医は一般に敬遠 しがちである、しかしながら, 臨床の場で, 慢性・急 性腎不全の病態を正しく把握するためには，他でもな い糸球体機能を理解する必要がある。特に今日, 血液 透析や腎移植が泌尿器科学の重要な課題のひとつにな りつつあり, 今後, 泌尿器科医のこの領域に対する関 心も強まるものと思われる。ささらに，ネフロンを河の 流れと仮定すると, 系球体はその源流を意味し, その 下流である尿細管など遠位部は系球体機能に大きく影 響を受け，その機能も大きく修飾されることから，腎 機能を正しく理解する上に重要である.

従来の腎機能検査は, 既に起った腎機能障害の程度 を評価する際には有用であった。もし，潜在的な腎臓
の予備能力をあらかじめ, 容易に測定する方法があれ ば，その臨床的応用価值は, 極めて高いものがある。 そこで腎予備能 renal functional reserve という魅力 的な概念が，新たに登場してきたわけだが，腎臓の複 雑な機能のすべてをカバーする予備能力を指している のではなく, その解釈にも多くの異論がある。ここで は, 腎予備能の概念を紹介し, 臨床に打ける最近の知 見を含めて概説する.

\section{II. 系球体滤過とその調節}

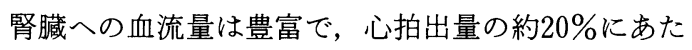
る1, $000 \sim 1,200 \mathrm{ml} / \mathrm{min}$ が流入し, 臟器重量あたりの 血流量からすると, 肝臓の 4 倍, 心冠血流量の約 8 倍 にも相当する ${ }^{122}$. 腎臓への血流は, 腎動脈より葉間動 脈・弓状動脈へと分岐し, 輸入細動脈 afferent arterioleをへて糸球体 glomerulus に至る ${ }^{3)}$. 系球体係蹄 glomerular capillary で流量約 $600 \sim 700 \mathrm{ml} / \mathrm{min}$ の血 浆から, 約 $120 \mathrm{ml} / \mathrm{min}$ が限外滤過 ultrafiltrationされ $ろ^{2}$. この限外濾過液 ultrafiltrate には, 蛋白が殆ど含 まれず，電解質成分は，血浆成分とほぼ同一である。 限外滤過液が全く再吸収を受けないとすれば, 1 日に 約 $170 l$ の尿が排泄され, これは総体液量をはるかに上 回ってしまう. 実際の 1 日尿量は 1 ～ $2 l$ であるから, 限 外濾過液の $99 \%$ が何らかの方法で，尿細管より再吸収 されなくてはならない，濾過を受けなかった血浆は， 輸出細動脈を経て, 皮質部では尿細管周囲を通り, 䯣 
質部では, 直血管 vasa recta となった後, 静脈系へと 流入する314).

腎臓の機能的単位であるネフロン nephronには, そ の存在する位置により, 浅在性ネフロン superficial nephron と深在性ネフロン deep nephron の 2 種類が ある3). 前者は, 短いヘンレ脚 Henle's loopを持ち, 皮質部ネフロン cortical nephronとも呼ばれ, 後者は 長いヘンレ脚を有し, 傍䯣質ネフロン juxtamedullary nephronとも呼ばれる。 ラットでは, ネフロンの $25 \%$ が長いヘンレ脚を持つネフロンであるが，ヒトでは， 浅在性ネフロンが 7 倍多いとされている3 ${ }^{3)}$. 当然ネ フロンを構成する系球体にも, その存在する位置によ り，機能に差があることが想像できるが，腎生理学上 得られる情報の多くは, 浅在性ネフロンの糸球体から である。これは微小穿刺法 micropuncture によって到 達できるのが浅在性の糸球体に限られるためである。 最近, 尿細管のみならず系球体についても, 微小単離 microdissectionにより, 微小潅流法 microperfusion が可能となり, 系球体機能研究の進展が期待されてい る.

1）糸球体限外濾過 glomerular ultrafiltration

尿産生の第 1 段階は, 血浆から系球体係蹄壁を通し ての限外滤過液の生成にある。この過程は, 他の毛細 血管と同様に，スターリングの法則 Starling's law に 従 万。つまり, 水圧較差 hydraulic pressure gradient ( $\Delta \mathrm{P})$ と膠質浸透圧較差 colloid osmotic pressure gradient $(\Delta \Pi)$ により決定される（図 1$)^{6}$.

糸球体係蹄における液量フラックス fluid flux $\left(\mathrm{J}_{\mathrm{v}}\right)$ をスターリングの法則により表現すると，

$$
\begin{aligned}
\mathrm{J}_{\mathrm{V}} & =\mathrm{K} \cdot(\Delta \mathrm{P}-\Delta \mathrm{\Pi}) \\
& =\mathrm{K} \cdot\left\{\left(\mathrm{P}_{\mathrm{Gc}}-\mathrm{P}_{\mathrm{T}}\right)-\left(\Pi_{\mathrm{GC}}-\Pi_{\mathrm{T}}\right)\right\}
\end{aligned}
$$

となる. 定数 $\mathrm{K} は$, 系球体係蹄壁の親和係数 permeability coefficient であり，P， П はそれぞれ, 糸球体係 蹄内 (GC) とボゥマン腔 Bowman's space 内 (T) の 水圧と膠質浸透圧とを示す。ここでボウマン腔での蛋 白濃度は, 非常に低いので, $\Pi_{\mathrm{T}}$ は無視できる. したがっ $\tau$, 膠質浸透圧較差 $(\Delta \Pi)$ は糸球体係蹄内膠質浸透圧 $\left(\Pi_{\mathrm{GC}}\right)$ と等しくなり,（1)式は,

$$
\mathrm{J}_{\mathrm{V}}=\mathrm{K} \cdot\left(\mathrm{P}_{\mathrm{GC}}-\mathrm{P}_{\mathrm{T}}-\Pi_{\mathrm{GC}}\right)
$$

と書き換えることができる。これを単一ネフロンあた りの糸球体濾過量 (single nephron glomerular filtration rate, SNGFR）として考えると，

$$
\mathrm{SNGFR}=\mathrm{K}_{\mathrm{f}} \cdot(\Delta \mathrm{P}-\Delta \Pi)
$$$$
=\mathrm{K}_{\mathrm{f}} \cdot \mathrm{P}_{\mathrm{UF}}
$$

図 1 系球体濾過に影響を及ぼす因子（記号について は本文参照）

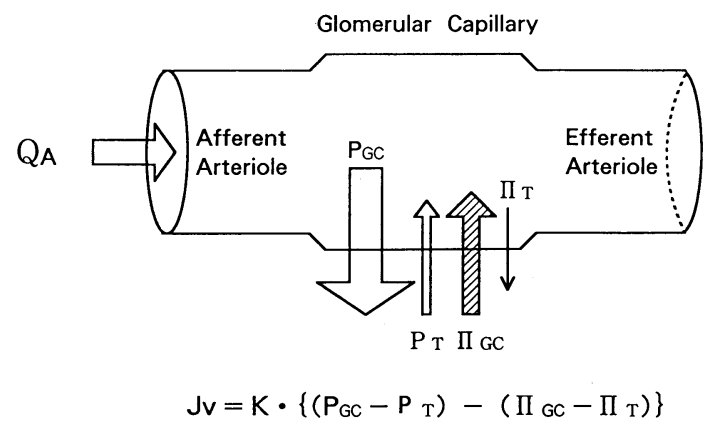

と表せる. SNGFRは限外滤過係数（ultrafiltration coefficient, $\mathrm{K}_{\mathrm{f}}$ ) と真の限外濾過圧 (net ultrafiltration pressure, $\left.\mathrm{P}_{\mathrm{UF}}\right)$ との積に等しい. 限外濾過係数 $\left(\mathrm{K}_{\mathrm{f}}\right)$ は糸球体係蹄壁の水透過性（k）と有効濾過面積（s） との積として表せるので $\left(\mathrm{K}_{\mathrm{f}}=\mathrm{k} \cdot \mathrm{s}\right),(3)$ 式は,

$$
\begin{array}{r}
\mathrm{SNGFR}=\mathrm{k} \cdot \mathrm{s}(\Delta \mathrm{P}-\Delta \Pi) \\
=\mathrm{k} \cdot \mathrm{s}\left(\mathrm{P}_{\mathrm{GC}}-\mathrm{P}_{\mathrm{T}}-\Pi_{\mathrm{GC}}\right)
\end{array}
$$

となる. SNGFRは(4)式に含まれた因子により変化 する.

正常ヒトの SNGFR は, $60 \mathrm{nl} / \mathrm{min}$ 程であるが, 総腎

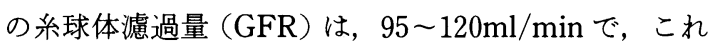
は筋肉毛細血管での濾過量の 1,000 倍にあたる.この大 容量の濾過能力は, $\mathrm{K}_{\mathrm{f}}$ の值が50 100倍高く, かつ系球 体限外滤過圧 $\left(\mathrm{P}_{\mathrm{UF}}\right)$ がより大きいためである ${ }^{1)}$.

$\mathrm{K}_{\mathrm{f}}$ を規定する因子については，良く理解されていな いが，正常では一定とされる．最近， $\mathrm{K}_{\mathrm{f}}$ は個体の持つ 糸球体の大きさに比例し，例えば，イヌはラットに比 べて $\mathrm{K}_{\mathrm{f}}$ 值が高いとの報告がある77. 糸球体係蹄壁の水 透過性 $(\mathrm{k})$ は種により一定であるから， $\mathrm{K}_{\mathrm{f}}$ の变化は主 として濾過面積 (s) の変化による. 糸球体係蹄の間に あるメサンギウム細胞は, 収縮線維を有し, いろいろ な血管収縮因子に反応して， s を低下させる ${ }^{2)}$.

Münich-Wistar rat での微小穿刺法により直接測定 した $\mathrm{P}_{\mathrm{Gc}}$ は 45 50 mmHg で，ボウマン腔内 $\mathrm{P}_{\mathrm{T}}$ は平均 $13 \mathrm{mmHg}$ 以下であるから, 水圧較差 $(\Delta \mathrm{P})$ は約 35 $\mathrm{mmHg}$ となる ${ }^{8) ~ 10)}$. 系球体の輸入及び輸出細動脈側で の水圧の低下は小さく, 系球体係蹄に沿って, $\Delta \mathrm{P}$ はほ ぼ一定と考兄られる(図 2)。これに対し，膠質浸透圧 較差 $(\Delta \Pi)$ は, 輸入細動脈側から, 輸出細動脈に向かっ て上昇する，限外濾過には蛋白が含まれず系球体係蹄 沿いに血浆蛋白濃度が徐々に增加するためである。 ラットでの測定では, 輸入細動脈側での蛋白濃度は 5 
図 2 糸球体係蹄における水圧較差と膠質浸透圧較差

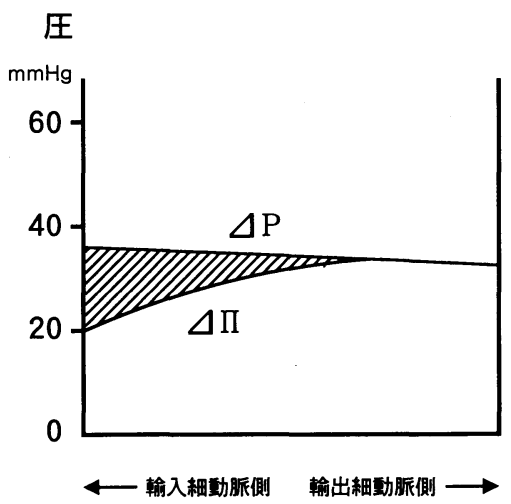

〜 $\mathrm{g} / \mathrm{dl}$ であるのに比し, 輸出細動脈側で, $8 \sim 9 \mathrm{~g} / \mathrm{dl}$ で あり,この値から計算された輸入細動脈側での $\Delta \Pi$ は, $20 \mathrm{mmHg}$, 輸出細動脈側では, $35 \mathrm{mmHg}$ となる ${ }^{6) 11)}$. 従って $\Delta \mathrm{P}$ と $\Delta \Pi$ の差として求められる真の限外濾過 圧差 $\mathrm{P}_{\mathrm{UF}}$, は図 2 の斜線の面積として求められる。 $\Delta \mathrm{P}$ と $\Delta \Pi$ の交点では, 真の限外濾過は 0 となり, 濾過圧平 衡 filtration pressure equilibrium に達する. 血清蛋白 濃度が増加するような病態, 高グロブリン血症, 多発 性骨髄腫では $\Delta \Pi$ が増加し， $\mathrm{P}_{\mathrm{UF}}$ が低下するため, SNGFR は減少する2).

一方, Пの増加は, 濾過比(filtration fraction, FF) に比例する. 単一ネフロンの濾過比(SNFF) は次の式 で表せる。

$$
\mathrm{SNFF}=\frac{\mathrm{NSGFR}}{\mathrm{Q}_{\mathrm{A}}}
$$

糸球体血浆流量 $\left(Q_{\mathrm{A}}\right)$ の増加は $\mathrm{SNFF}$ の低下をもたら し, 系球体係蹄内での $\Delta \Pi$ の増加の程度が減少する. 従って $\mathrm{P}_{\mathrm{UF}}$ は増加し, SNGFR 上昇の方向に㗢く. 腎摘 後の単腎1213)，あるいは糖尿病にみられる SNGFR の 上昇 (糸球体過剰濾過 glomerular hyperfiltration) は, $\mathrm{Q}_{\mathrm{A}}, \mathrm{P}_{\mathrm{UF}}$ の増加による ${ }^{14)}$. また, $\mathrm{Q}_{\mathrm{A}}$ の増加は, 輸出入 細動脈における血管抵抗の低下に起因する ${ }^{13) 14)}$.

2) 糸球体濾過の自己調節 (autoregulation)

GFR の決定因子の一つとして， $\mathrm{P}_{\mathrm{GC}}$ が重要であるこ とは, 前項で述べた. 腎動脈圧の小さな変化が GFR の 大きな変化をもたらすはずであるが，実際には，GFR の変化も小さい，腎動脈圧の変化にかかわらず GFR とRPF を一定に保つ働きが認められる. 除神経腎や， 単離潅流腎でも同様の現象が観察できることから，こ の調節系は，腎内部に存在すると考えられるので，“自 己調節 autoregulation”と呼ばれる。輸入細動脈の血
管抵抗の変化が自己調節系では最も重要な役割を果た している15)16).

全身の血圧が上昇した時には，輸入細動脈が収縮す ることにより $\mathrm{P}_{\mathrm{GC}}$ の上昇が押さえられ， SNGFRの上 昇を抑制する。逆に血圧が下がった時には輸入細動脈 は抎張して，GFR，RPFの低下を防止する。しかしな がら血圧が70 80 $\mathrm{mmHg}$ 以下になると自己調節系は 機能せず，さらに40～50mmHg 以下では GFR はほぼ 0 になる ${ }^{16)}$.

自己調節系の機序について最も単純な考方方は筋原 説 ${ }^{17)}$ で, 輸入細動脈壁内の伸展受容体が腎潅流圧上昇 時に, 伸展されると, 平滑筋が収縮して $\mathrm{P}_{\mathrm{GC}}$ の上昇を抑 制し, 腎潅流圧が低下すると, 平滑筋緊張が弛緩する. しかし，この筋原説のみで腎の複雑な自己調節機能を 全て説明することはできない.レニン・アンギオテン シン系を含めた，尿細管・系球体フィードバック (tubuloglomerular feed back) 機構が関与しているも のと考えられている.

3）尿細管・糸球体フィードバック（tubuloglomerular feed back)

ヘンレ上行脚の終末部（緻密斑, macula densa）は 糸球体及び，輸入・輸出細動脈に近接し，尿細管レベ ルでの出来事を糸球体に伝達するネフロン内フィード バックにふさわしい解剖学的位置関係にある。実際 ラット in vivoでの微小穿刺法による尿細管微小潅流 法により，緻密斑への容量負荷が同一ネフロンの SNGFR を低下させたことから, 尿細管・糸球体フィー ドバック機構の存在が提唱された ${ }^{18) 19)}$. 緻密斑によっ て関知されるシグナルの因子としては，尿細管内王・ 尿細管液内浸透圧・ナトリウム濃度等が候補とされた。 中でも尿細管内潅流液の $\mathrm{Na}$ 濃度と SNGFR が負の 相関を示すことから, 尿細管内 $\mathrm{Na}$ 濃度の変化が, 最初 のシグナルであると考えられた ${ }^{19)}$.つまり, $\mathrm{Na}$ 濃度の 上昇を緻密斑で関知し，傍系球体装置（juxtaglomerular apparatus, JGA）よりのレニン産生分泌が増加 し，アンギオテンシンが腎血管収縮に働いて GFRを 低下させると説明したわけである。その後 Schnermann らが, $\mathrm{Na}$ 濃度, 浸透圧とも同一であるが, 組成 の違う潅流液を用いて, ヘンレ脚を潅流し, 負のフィー ドバックは, 潅流液中に $\mathrm{Cl}$ を含むときのみに生じ, $\mathrm{Na}$ 濃度, 浸透圧には関係しないことを明らかにした 20121). 利尿剂により $\mathrm{Cl}$ インン輸送をブロックすると,

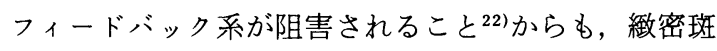
における尿細管細胞での $\mathrm{Cl}$ 再吸収の増加が重要なシ 
図 3 尿細管・系球体フィードバック現象

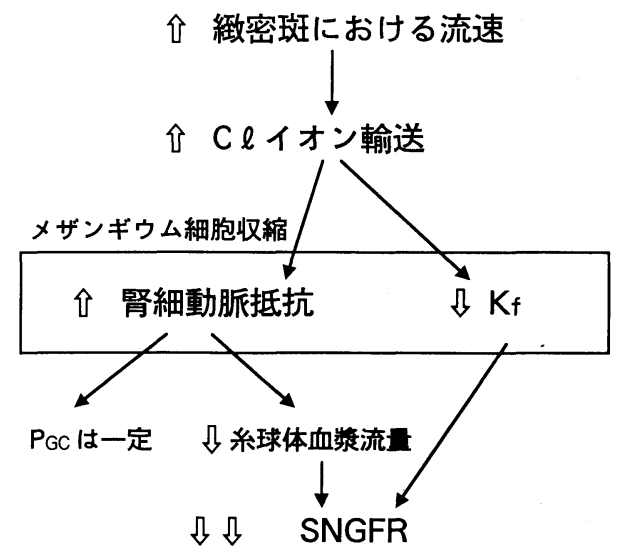

グナルであると考劣られる。

フィードバック機構の糸球体への作用機序の解明 は, Ichikawa らの研究に負らところが多い23). 微小潅 流法により遠位尿細管への流速を 0 から40 $\mathrm{nl} / \mathrm{min}$ ま で増加させると SNGFRは，35\%減少した。この SNGFR の低下は, メサンギウム細胞の収縮による濾 過面積 (s) の減少と細動脈血管抵抗の増大による $\mathrm{Q}_{\mathrm{A}}$ の 減少が主因であり,この際, $\mathrm{Q}_{\mathrm{A}}$ の低下に比べると, $\mathrm{P}_{\mathrm{GC}}$ は一定していた(図 3 ). 更に最近では, 両生類の一種 であるアンヒューマAmphiumaを使用した実験か ら，JGA 間質のイオン構成が重要であること ${ }^{24) 25)}$. 間 質での $\mathrm{NaCl}$ 濃度が増加すると, Goodmaghtigh 細胞 に感知され, 細胞間にある gap junction に coupling が生ずることにより, 細動脈及びメサンギウム細胞の 収縮に働いているとの報告もある ${ }^{26) ~ 28) . ~}$

4）神経性及びホルモンによる糸球体濾過の調節

メサンギウム細胞や, 輸出, 輸入細動脈にアドレナ リン作動性の神経終末が存在することは電顕的にも証 明されているが29)30). 正常あるいは病的状態における, 腎の神経支配の意義はいまだ不明である，腎神経への 電気的刺激は，腎血管収縮をもたらし，SNGFR と $Q_{A}$ は並行して15～50\%低下する.作用機序としては輸出, 輸入細動脈血管抵抗の増加に加えて, メサンギウム細 胞の収縮による濾過面積 $(\mathrm{s})$ の縮小に起因する $\mathrm{K}_{\mathrm{f}}$ の低 下が考えられている6).

系球体には，アンギオテンシンII，インスリン, $\mathrm{ADH}, \mathrm{PTH}$, プロスタグランジン, ヒスタミン, セロ トニン, ドパミン，ノルェピネフリン，デキサメサゾ ンなど，多くのホルモン受容体が存在する6)31).アンギ オテンシン II $\mathrm{ADH}$ は, 培養メサンギウム細胞の収
縮に働くが，PTH や $\mathrm{PGE}_{2}$ にはこの作用が見られな (32). PTH, $\mathrm{ADH}, \mathrm{PGE}_{2}$, セロトニン, ヒスタミン, ドパミン,ノルエピネフリンは, 糸球体での cAMP 産 生を調節することにより，機能を発現している可能性 がある. cAMP は同時に, レニン産生を促進させるの で，これらのホルモンは，間接的に局所アンギオテン シンIIレベルを上昇させる作用もある。アンギオテン シンII, ルエピネフリン, cAMP, ADH, PTH, $\mathrm{PGE}_{2}$ は主として血管収縮に働き, $\mathrm{PGE}_{1}$, ヒスタミン, デキ サメサゾン, ブラジキニンは, 血管拡張に働くと言わ れている。

\section{III. 腎予備能}

1) 概念

健常人での糸球体濾過量 GFR は, 水の摂取量, 運動 量により，また昼間と夜間とでは，ごく僅かに変動が 見られるものの，泀汪一定している。言い換えれば, GFR を一定に保つことを目的として, 今まで述べて来 た様々な生理的機構が働いていると言える。

従来から，蛋白揁取がヒトでもイヌ，ラット，アザ ラシなどの動物でも，GFR と腎血浆流量 RPFを増加 させることが認識されていた，Wisemann らは，菜食 主義者と普通食摂取者とで GFRを比較し，蛋白摂取 量の極端に少ない, 厳格な菜食主義者では, 確かに GFR が低下していることを証明した ${ }^{33)}$.

Bosch らは，蛋白摂取とそれに反応しての GFRの 増加といら現象に注目して, 腎予備能“renal functional reserve”なる新しい概念を1983年に初めて記載 した ${ }^{34)}$. 彼らは, 通常一定している GFR を増加させる 負荷手段の 1 つとして, 蛋白摂取を利用したわけであ る。従って, 腎予備能は“The capacity of the kidney to increase its level of operation under certain demands”之定義されている.つまり, 心臓が生理的要 求に応じて, 心拍出量を増加させるように, 腎藏もネ フロンの総てが最大限の機能を発揮したポイントを以 て，腎予備能と想定したわけである（図 4).

彼らがこのような概念を提唱した背景には，腎不全 を進行させる機序の有力な仮説となっている過剰濾過 説 hyperfiltration theory の存在を無視することはで きない14)35) 37). 過剒濾過説とは, 要約すると, 最初何 らかの原因で一部のネフロンが障害を受けると, 比較 的健全な他のネフロンの機能を代償性に克進させる。 II で述べた SNGFR 増加, 特に $\mathrm{P}_{\mathrm{GC}}$ が亢進し, 過剰濾 過の状態になるわけである。この現象自体が糸球体を 障害し，悪循環となって，腎機能廃絶に至る。高蛋白 
図 4 腎予備能の概念

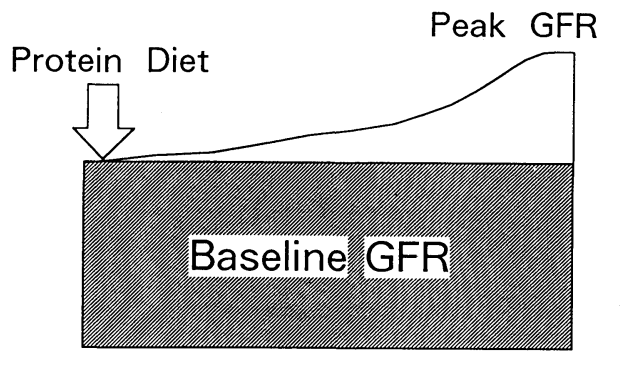

Renal Functional Reserve (RFR) $=$ Peak GFR-Baseline GFR

\section{図 5 急速蛋白負荷（牛肉）の GFRに及ぼす影響}

- 牛肉摂取時, ○対照日, ${ }^{*} \mathrm{p}<0.05$ （文献41より引

用)

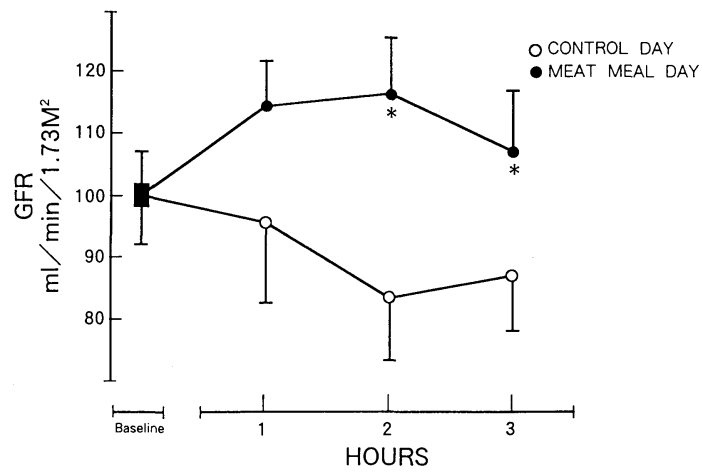

食は過唾濾過に促進的に働き，低蛋白食は抑制的に働 くことが報告されている ${ }^{38) 39}$. そこで，高蛋白食を与 え, 人為的に過剰濾過の状態をつくりだすことにより, その程度が潜在的に残された濾過機能を反映すると想 定したのである。

しかしながら，過㮃濾過説に対する反論も最近出さ れてきている ${ }^{40)}$. 急速蛋白負荷に対する腎血行動態の 変化と, 過剰濾過説との直接的な因果関係は, 証明さ れていず.むしろここでは，長期間高蛋白投与の腎機 能への影響とは区別して考えることにする.

2）健常者での腎予備能

図 5 にHostetter らにより報告された，調理牛肉を 摂取させた後の，健常者での GFRの推移を代表的な 例として示す ${ }^{411}$. 対象と比較して, 蛋白摄取の 2 時間後 にイヌリンクリアランス $\left(\mathrm{C}_{\mathrm{IN}}\right)$ より求められた $\mathrm{GFR}$ は約20\%増加している，急速蛋白負荷による腎予備能 の評価方法については，いまだ定まった方法はない。
表 1 に, 健常対照者数, 負荷方法が明記され, base-line GFR の差を無くするために, GFR の絶対值ではなく， GFR の増加を\%上昇率として計算できる報告をまと めた ${ }^{34) 41) ~ 49)}$. 全く GFRの上昇の見られないものから, 60\%近く増加するものまで幅広い. しかも同一グルー プからの報告を見ても ${ }^{34242) 45)}, 24 \%$ - 58\%と幅があり, 腎予備能の正常域を果してぞこまでとすべきか，困惑 する結果である。これは，負荷する蛋白の種類・量の 違い, 負荷試験前の蛋白摂取習慣の違(50) 52), 腸管で の吸収率の個体差，水利尿の程度などにより，影響さ れるためと思われる。また，GFRの測定法から生ずる 相違である可能性もある。

表 1 からも分かるように，調理牛肉蛋白を摂取した 時の GFR の上昇率は，一般的に高い傾向にある.同一 対象者に同一重量ではあるが，異なる種類の蛋白を摂 取させ, GFR 上昇率の違いを検討した報告によれば, 牛乳蛋白摂取時は, 殆ど上昇しなかったとする結果 と ${ }^{43)}$ ，牛肉摂取時に比べて低いが上昇が見られたとす る報告がある ${ }^{46) 49)}$. Jones らが“Casilan”と呼ばれる牛 乳蛋白では, GFR は上昇しないと報告したこと致を受 けて, Manssy らは,アミノ酸組成が殆ど同じで, リン 酸含量だけが異なる“Maxipro”で追試したところ, $\mathrm{C}_{\mathrm{IN}}, \mathrm{C}_{\mathrm{Cr}}$ の同程度の増加を認めた。この結果から, 彼ら は以前の Jonesらの成績が理解できないとしながら も,アミノ酸組成の差によるものか, 消化管での消化・ 吸収過程に差があると，推察している ${ }^{53)}$.

腎予備能の測定に関するもら一つの問題としては, GFR の測定方法が重要である。 $\mathrm{C}_{\mathrm{IN}} \cdot \mathrm{C}_{\mathrm{Cr}}$ を同時に測定 し比較した報告では, 両者とも同程度に増加してい る34)48). しかし， $\mathrm{C}_{\mathrm{Cr}}$ の最高值に達するまでの時間が, $\mathrm{C}_{\mathrm{IN}}$ に比べて, 2 時間程遅れること, 又, 時間経過とと もに, 血中 $\mathrm{Cr}$ 濃度・尿中 $\mathrm{Cr}$ 排泄が優位に増加するこ とを指摘した ${ }^{48)}$. 特に, 調理牛肉を蛋白負荷源とした場 合には, $1.5 \mathrm{mg} / \mathrm{g}$ 重量の外因性クレアチニン負荷を 行ったと同じことになり ${ }^{54)}$, 近位尿細管よりのクレア チニン分泌を増加させる結果となる55).

実際, 蛋白負荷後90分までは，尿細管よりクレアチ ニン分泌は 0 であったが，90分以後には，15.7\%にま で増加したとの実験結果があり ${ }^{48)}$, 腎予備能を $\mathrm{C}_{\mathrm{cr}}$ の みで測定すると，過剰評価してしまう危険性がある。

3）急速蛋白負荷による過唾濾過 hyperfiltrationの 機序

急速蛋白負荷に対する SNGFR の変化について検 討した報告は殆ど無い. IIで述べたように, SNGFR 
表 1 急速蛋白負荷による GFR の上昇

\begin{tabular}{|c|c|c|c|c|c|}
\hline 報 告 者 & 対象人数 & 蛋白の種類 & GFR 測定法 & GFR 上昇率 & 報告年 \\
\hline 1) Bosch et $\mathrm{al}^{34 \text { ) }}$ & 4 & $\begin{array}{l}\text { 調理牛肉 } \\
80 \mathrm{~g}\end{array}$ & $\begin{array}{l}\mathrm{C}_{\mathrm{IN}} \\
\mathrm{C}_{\mathrm{Cr}}\end{array}$ & $\begin{array}{l}58 \% \\
52 \%\end{array}$ & 1983 \\
\hline 2) Bosch et $\mathrm{al}^{42)}$ & 16 & $\begin{array}{l}\text { 調理牛肉 } \\
70 \sim 80 \mathrm{~g}\end{array}$ & $\mathrm{C}_{\mathrm{IN}}$ & $28 \%$ & 1984 \\
\hline 3) Jones et $\mathrm{al}^{43 \text { ) }}$ & 10 & $\begin{array}{c}\text { 調理牛肉 } \\
90 \mathrm{~g} \\
\text { 牛乳蛋白 } \\
900 \mathrm{~g}\end{array}$ & $\begin{array}{l}\mathrm{C}_{\mathrm{Cr}} \\
\mathrm{C}_{\mathrm{Cr}}\end{array}$ & $\begin{array}{l}18 \% \\
\text { None }\end{array}$ & 1985 \\
\hline $\begin{array}{l}\text { 4) Rodriguez- } \\
\text { Iturbe et } \mathrm{al}^{44)}\end{array}$ & 44 & $\begin{array}{l}\text { 調理牛肉 } \\
100 \sim 150 \mathrm{~g}\end{array}$ & $\mathrm{C}_{\mathrm{Cr}}$ & $49 \%$ & 1985 \\
\hline 5). Bosch et al ${ }^{45)}$ & 7 & $\begin{array}{l}\text { 調理牛肉 } \\
70 \sim 80 \mathrm{~g}\end{array}$ & $\mathrm{C}_{\text {IN }}$ & $24 \%$ & 1986 \\
\hline 6) Hostetter et $\mathrm{al}^{411}$ & 10 & $\begin{array}{l}\text { 調理牛肉 } \\
4 \mathrm{~g} / \mathrm{BWkg}\end{array}$ & $\mathrm{C}_{\mathrm{IN}}$ & $18 \%$ & 1986 \\
\hline 7) Dhaene et $\mathrm{al}^{46)}$ & 6 & $\begin{array}{l}\text { 調理牛肉 } \\
\text { 牛乳蛋白 } \\
2 \mathrm{~g} / \mathrm{BWkg}\end{array}$ & $\mathrm{C}_{\mathrm{Cr}_{\mathrm{r}}}$ & $\begin{array}{r}28 \% \\
8 \%\end{array}$ & 1987 \\
\hline 8) Mizuiri et $\mathrm{al}^{47)}$ & 12 & $\begin{array}{l}\text { 調理鶏肉 } \\
50 \mathrm{~g}\end{array}$ & $\begin{array}{l}{ }^{99 m} \text { Tc- } \\
\text { DTPA }\end{array}$ & $14 \%$ & 1988 \\
\hline 9) Laville et al ${ }^{48)}$ & 9 & $\begin{array}{l}\text { 調理牛肉 } \\
90 \mathrm{~g}\end{array}$ & $\begin{array}{l}\mathrm{C}_{\mathrm{IN}} \\
\mathrm{C}_{\mathrm{Cr}}\end{array}$ & $\begin{array}{l}26 \% \\
26 \%\end{array}$ & 1989 \\
\hline 10) Bilo et $\mathrm{al}^{49)}$ & 6 & $\begin{array}{c}\text { 大豆蛋白 } \\
\text { 牛乳蛋 } \\
\text { 牛肉蛋白 } \\
80 \mathrm{~g}\end{array}$ & $\begin{array}{l}125 \mathrm{I}- \\
\text { iothalamate }\end{array}$ & $\begin{array}{l}11 \% \\
14 \% \\
19 \%\end{array}$ & 1989 \\
\hline
\end{tabular}

は，(1) $\Delta \mathrm{P}$ ，(2) $\mathrm{K}_{\mathrm{f}}$ ，(3) $\Delta \Pi ，$ (4) $\mathrm{Q}_{\mathrm{A}}$ により決定される. 長期蛋白負荷による SNGFR の増加は，まず(4) $\mathrm{Q}_{\mathrm{A}}$ の 増加で一部説明できるといら。 Ichikawa らは長期間 の高蛋白摂取は, (2) $\mathrm{K}_{\mathrm{f}}$ が高くなることを示し ${ }^{56)}$, 又, Hostetter らは, (1) $\Delta \mathrm{P}$ を重視した ${ }^{14)}$.このような長期 間での成績を，そのまま急速負荷でも同様であるとは 解釈できないが，急速負荷でも $\Delta \mathrm{P}$ が増加するとの報 告が最近ある ${ }^{57)}$. しかしながら糸球体レベルでの機序 については，まだなお不明と言わざるを得ない。

ヒトでは，急速蛋白負荷後に有意の腎血管抵抗の減 少があることから ${ }^{4151)}$ ，蛋白負荷が輸入細動脈の拡張 に作用している可能性が推察されている。この作用は, 蛋白が分解されたアミノ酸の直接作用であるのか，腎 内の電解質, エネルギー代謝を変化させることにより, 二次的に働いているのか ${ }^{58)}$ ，あるいは血管作動性の木 ルモンを仲介として，作用を発現するのか，現在議論 の焦点になっている.

\section{a）蛋白・アミノ酸と過㮃濾過}

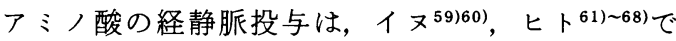
GFR を増加させることが知られている．多くは，混合 アミノ酸溶液の点滴静注を行いその作用を見てい $3^{61) ~ 66)}$. 単一種類のアミノ酸投与の実験では, プロリ
ン59)，アラニン60)がイヌで，ヒトではアルギニンが GFR を上昇させたとの報告がある67)68). いずれの実験 でも，負荷されるアミノ酸の量は，中心静脈栄養患者 に与えられる量の $1.5 \sim 2$ 倍に達し ${ }^{63669)}, 200 \mathrm{~g}$ の蛋白 食を与えられたのと，同程度量と換算される。アミノ 酸が直接作用して，血管拡張に働くといら報告もある が70)，血浆中のアミノ酸レベルが負荷前に戻ってから もなお GFR・RPF の上昇は続いているので，主因とは 考えにく(64)69)。一方，アミノ酸は，近位尿細管で $\mathrm{Na}$ 依存性共輸送により再吸収される。アミノ酸負荷を行 ら近位尿細管での $\mathrm{Na}$ 再吸収が増加し, 遠位への溶 質負荷が相対的に減少することにより；尿細管・糸球 体フィードバック系が働いて, GFR が増加するという 考方方もあが67)，逆にこのフィードバック系への抑 制が低下しているために, GFR が上昇するとの実験結 果もあり ${ }^{71)}$, 結論は出ていない。

b）蛋白・アミノ酸・ホルモンと過剩濾過

前述したように(II-4), 系球体には多くのホルモン 受容体が存在する。アミノ酸あるいは急速蛋白負荷に よる過剰濾過の機序としては, ホルモンの役割が現在 最も注目されている。中でもグルカゴンは，アミノ酸 あるいは蛋白負荷の際，血浆中濃度が上昇するこ 
と63(64)66) 68)72)73)，グルカゴン投与により過唾濾過反応 が出現することから 52)74) 76), 中心的ホルモンと推察さ れてきた。ところが，グルカゴンが過㮃濾過を促すた めには，薬理学的用量が必要で，アミノ酸・蛋白負荷 によって増加する生理的なグルカゴンの血浆レベルで は, GFR・RPF に影響しないことが分かってきた ${ }^{77)}$. さらに，肝機能の低下している肝硬変患者では，急速 蛋白負荷による増加が見られないこと ${ }^{78)}$, 生理的レべ ルのグルカゴン $(3 \mathrm{ng} / \mathrm{kg} / \mathrm{min})$ をイヌの門脈に投与し たところ, GFR・RPF の増加が観察されたことから ${ }^{72)}$, 肝蔵を介する調節系の存在が示唆されている，以前か ら, 肝藏で産生され腎に作用して GFR を増加させる, 末知の物質 “glomerulopressin”が想定されている が79)80)，いまだ同定，分離，生成されて打らず，はっき りしない. 成長ホルモンにも, GFR・RPFを増加させ

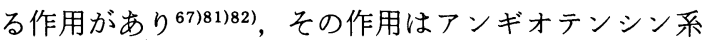
を介していないとされている ${ }^{82)}$.蛋白・アミノ酸を負荷 すると一過性に血奨中成長ホルモンのレベルが上昇す る.また，ヒトで数日間成長ホルモンを投与すると， $\mathrm{GFR} \cdot \mathrm{RPF}$ の増加が見られる. 巨人症では GFR・RPF が体表面積に比べ高く，逆に成長ホルモン欠乏による 小人症では, 蛋白負荷による過唾濾過反応が起こらな いことが報告されている，以上が成長ホルモンが mediatorの一つとして考えられる根拠とされて来た わけである. Hirschberg らは, 成長ホルモンの存在が, アミノ酸投与により誘導される過刮濾過の過程に必須 であるかどらかを再検討したが，成長ホルモン欠乏症 の方が，対照者に比べ, RPF と GFR の増加率が高い といら結果を得た ${ }^{67)}$. このことからも成長ホルモンが 過剰濾過の mediator の主役とは考えにくい.

その他, 議論の対象となっているホルモン因子とし ては, プロスタグランディン系がある，高蛋白質の摂 取は腎での $\mathrm{PGE}_{2}, \mathrm{PGF}_{2}, \mathrm{TXB}_{2}$, 6-keto $\mathrm{PGF}_{1} \alpha$ の 産生を増加し, GFR 上昇に作用するとの実験結果が報 告されている7383884). 更に, アンギオテンシン系65), あ るいはカリクレインーキニン系 ${ }^{86)}$ が部分的に関与して いると主張するグループもある，以上のごとく，どの ホルモンの実験結果を見ても mediatorの主役とする には不足している. mediator として単一ホルモンが働 いているのではなく, いくつかのホルモン系が複雑に 腎での代謝，輸送系と関連して働き，過剰濾過といら 現象に結びついているものと思われる（図6）.

c）ドパミンと腎予備能

蛋白負荷による腎予備能評価の最大の欠点は, 蛋白
図 6 蛋白負荷が過剰濾過を引き起こす機序

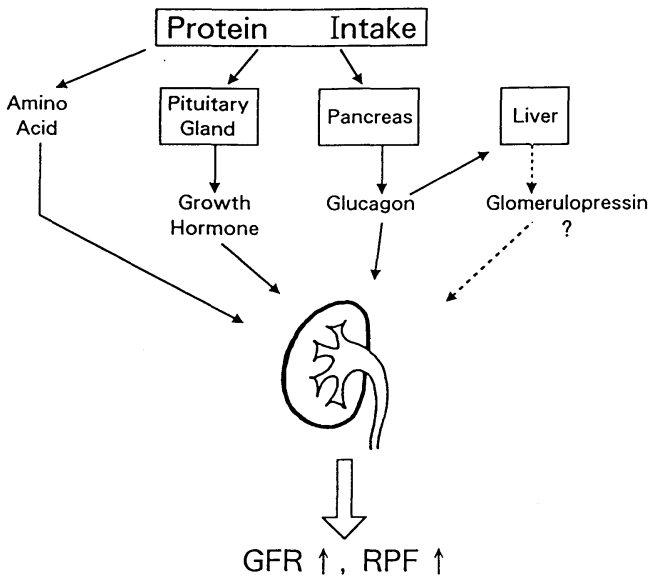

の種類や量を一定にできず，そのうえ消化・吸収に個 体差があるため，比較検討が困難なことである。これ に対し，アミノ酸投与，あるいは，グルカゴン投与は， より客観的な評価を持ち得る. ter Weeらは,ドパミ ン,アミノ酸の単独投与では GFRの上昇率が，それぞ れ $12 \% ， 10 \%$ と低かった反応が，アミノ酸とドパミン を同時に投与することにより GFR の上昇率が $22 \%$ ま で増加することを示し，腎予備能の検討には，両者併 用が良いと主張している ${ }^{62)}$. 全身の循環系(血圧, 脈拍) を変化させない低濃度のドパミンを単独に投与し， GFR・RPF の変化量により腎予備能を評価しょうと する試みも最近行われている87 899. しかしドパミンに よる腎血液流量の上昇が，必ずしもGFR を増加させ ないことからも，蛋白負荷や，アミノ酸投与と同質の 刺激を与えていることになるかどうかについては，明 確な説明が与えられていない。

\section{IV．腎予備能と臨床}

\section{1）移植腎}

移植腎について，腎予備能を検討した臨床報告は少 ない,90) 92). Dhane らは，7例の腎移植後患者に調理牛 肉負荷による腎予備能の測定を行い，3 例に $20 \%$ 前後 の GFR の増加を認めたが， 4 例は GFR が上昇しな かった ${ }^{90)}$. 服部らは，小児腎移植患者を腎機能良好群 と，腎機能低下群とに分けて，ドパミン負荷試験を行 い, 腎機能の予後を知るらえで, 有用な検査になり得 ることを示唆した ${ }^{91)}$.

我々は, (1)蛋白負荷による移植腎の腎血行動態の変 化，(2)免疫抑制療法の違いにより差があるか，(3)移植 腎機能の予後を推測するらえで有用かといら観点から 
表 2 急速蛋白負荷の対象群

\begin{tabular}{l|c|c|c}
\hline \multicolumn{1}{c|}{ Group } & No. & $\begin{array}{l}\text { Months after } \\
\text { Operation }\end{array}$ & $\begin{array}{c}\text { baseline } \\
\mathrm{GFR} \\
\left(\mathrm{ml} / \mathrm{min} \cdot 1.73 \mathrm{~m}^{2}\right)\end{array}$ \\
\hline Control & 5 & $15.0 \pm 13.0$ & $60.7 \pm 3.2$ \\
Azathioprine & 8 & $50.5 \pm 6.8$ & $41.9 \pm 3.8^{*}$ \\
Cyclosporine A & 8 & $9.1 \pm 4.0$ & $41.3 \pm 3.6^{*}$ \\
\hline
\end{tabular}

${ }^{*} \mathrm{p}<0.05$

因 7 腎予備能（RFR）と GFRの\%上昇率 Aza : Azathioprine 群, CsA : Cyclosporine 群
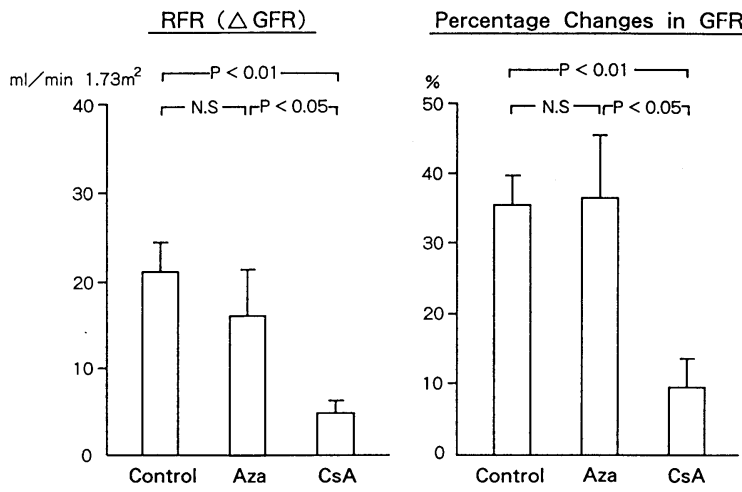

腎移植患者について調べた。対象とした患者は，表 2 に示す様に，腎ドナー 5 人を対照とし，イムラン，プ レドニンによる従来からの免疫抑制療法を受けていた もの 8 人, シクロスポリンを加光た 3 者併用療法を 行っていた 8 人の合計 21 人で, 死体腎移植患者は 2 例 のみで, 他は全て生体腎移植患者であった。魚肉蛋白 $2.0 \mathrm{~g} / \mathrm{BW} \mathrm{kg}$ を摂取させ, イヌリン・PAH クリアラン スにより, 負荷前後の GFR, RPF を測定し, 腎予備能 を評価した。

結果は図 7 に示した通り, 腎予備能は対照群, イム ラン群がそれぞれ $21 \mathrm{ml} / \mathrm{min} \cdot 1.73 \mathrm{~m}^{2}, 16 \mathrm{ml} / \mathrm{min} ・ 1.73$ $\mathrm{m}^{2}$ と高くシクロスポリン使用群では $4 \mathrm{ml} / \mathrm{min} \cdot 1.73 \mathrm{~m}^{2}$ と明かに低下していた。これを GFR の\%上昇率とし て比較してみても, 対照群, イムラン群が各々 $35 \%$, 37\%であったのに対し，シクロスポリン群では，9\% にすぎなかった。同時に行った血圧測定の結果から， 腎血管抵抗を計算し比較してみると（図 8) シクロス ポリン群では, 蛋白負荷の際に腎血管抵抗減少の程度 が他の群に比較して，極めて少なかったことが分かっ た.

この実験結果から, 移植された腎臓でも, 過剩濾過 反応が起こることが確認された。、又，イムラン，プレ
図 8 蛋白負荷後の腎血管抵抗の減少 Aza : Azathioprine 群, CsA : Cyclosporine 群

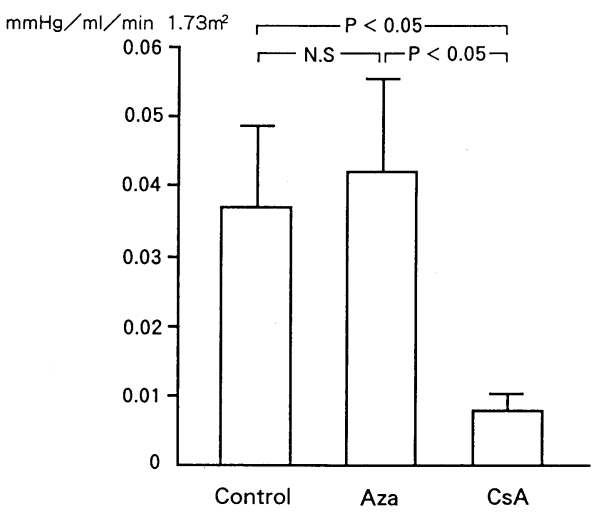

ドニン, シクロスポリンの免疫抑制療法の違いにより, 腎予備能に差があることも明らかとなった。しかしシ クロスポリン群で腎予備能が低下していた原因の解釈 は難しい.1つの可能性としてはシクロスポリン群で は, 既に糸球体への負荷が過㮃になっていて, 濾過容 量が最大限の状態にあるためかも知れない。もう 1 つ の解积としては, シクロスポリンの作用により輸入細 動脈の tonus が高まっているため, 蛋白負荷の刺激で は，血管拡張が充分に行われず, GFRが上昇しなかっ た可能性が考兄られる。腎機能障害促進因子として過 剰濾過説が正しいと仮定するなら，前者の解釈では, シクロスポリン群の腎機能はよりすみやかに低下する 可能性があり，後者の解釈をとるならば，シクロスポ リンは，腎臓を過㮃濾過から防ぐ作用を有することに なる、最近，アミノ酸負荷により同様の結果が報告さ れている92).

\section{2）糸球体疾患}

各種腎疾患の, 腎予備能について調べた報告を表 3 にまとめた，健常者と比較して低下しているとする結 果と, 变わらないとする報告がある. Bosch らは, base-line GFR の程度によって腎疾患患者を 4 群に分 け，GFRの上昇率を調べた。 GFR が $130 \mathrm{ml} / \mathrm{min} ・ 1.73$ $\mathrm{m}^{2}$ 以上の患者でも腎予備能は低下しており, base-line GFRのレベルとは関係しないとした ${ }^{42)}$ 。しかしなが ら, 蛋白負荷後 GFR が $47 \%$ も昇したとの報告もあ $\eta^{93)}$, 又低蛋白摂取時でも高蛋白摂取時でも，GFRの 上昇率には関係なく，健常者と差がないという成績も あり ${ }^{49)}$, 一定の見解が得られていない. 腎系球体疾患の 中でも, 糖尿病性腎症は特異で, 蛋白負荷を行っても 全く, GFR は上昇しない42)。これは, 糖尿病による代 
表 3 腎疾患と腎予備能

\begin{tabular}{|c|c|c|c|c|c|}
\hline 報告者 & 対象疾患 & 人数 & 負荷方法 & GFR 上昇率 & 健常者との比較 \\
\hline $\begin{array}{l}\text { Bosch 5 } 5^{42)} \\
(1984)\end{array}$ & 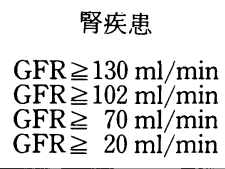 & $\begin{array}{r}31 \\
4 \\
13 \\
9 \\
5\end{array}$ & $\begin{array}{l}\text { 調理牛肉 } \\
70 \sim 80 \mathrm{~g}\end{array}$ & $\begin{array}{r}11 \% \\
14 \% \\
15 \% \\
9 \%\end{array}$ & 低下 \\
\hline $\begin{array}{l}\text { Rodriguetz- } \\
\text { Iturbe } 5^{44)} \\
\quad(1985)\end{array}$ & 急性腎炎後 & 35 & $\begin{array}{l}\text { 調理牛肉 } \\
100 \mathrm{~g}\end{array}$ & $10 \%$ & 低下 \\
\hline $\begin{array}{c}\text { Bosch 5 55) } \\
(1986)\end{array}$ & $\begin{array}{l}\text { 腎系球体疾患 } \\
\text { 糖尿病性腎症 }\end{array}$ & $\begin{array}{l}10 \\
18\end{array}$ & $\begin{array}{l}\text { 調理牛肉 } \\
70 \sim 80 \mathrm{~g}\end{array}$ & $\begin{array}{r}21 \% \\
-12 \%\end{array}$ & 低下 \\
\hline $\begin{array}{l}\text { 服部ら } \text { (19) }^{(1987)}\end{array}$ & 小児腎炎 & 16 & $\begin{array}{c}\text { Dopamine } \\
1-3 \mu \mathrm{g} / \mathrm{kg} / \mathrm{min}\end{array}$ & $24 \%$ & $(-)$ \\
\hline $\begin{array}{c}\text { Mizuiri } 5^{47)} \\
(1988)\end{array}$ & ネフローゼ症候群 & 12 & 調理鷄肉 & $9 \%$ & 低下 \\
\hline $\begin{array}{c}\text { Zuccala Б93) } \\
(1989)\end{array}$ & 系球体腎炎 & 20 & $\begin{array}{l}\text { 調理牛肉 } \\
1.2 \mathrm{~g} / \mathrm{kg}\end{array}$ & $47 \%$ & 不変 \\
\hline $\begin{array}{c}\text { Bilo } 5^{49)} \\
(1989)\end{array}$ & 慢性腎機能障害 & 9 & $\begin{array}{l}\text { 調理牛肉 } \\
80 \mathrm{~g}\end{array}$ & $\begin{array}{l}20 \% \\
\text { （低蛋白食時） } \\
\text { (高蛋白食時) }\end{array}$ & 不変 \\
\hline
\end{tabular}

謝レベルでの変化が, 腎での低酸素に加光, 高血糖, 成長ホルモン, グルカゴンが関与し, 既に過㮃濾過の 状態にあるためと言われている94).

腎予備能によって腎機能の予後を推測し，なおかつ 実際の腎機能を系統的に追跡して比較した報告は無 い. base-line の GFR と腎予備能とが正の相関を示す ならば，腎予備能の少ない症例は腎機能低下の速度が 早く, 腎予備能が多い症例は, 腎機能低下の速度が遅 いと，ある程度推測できるが必ずしも，相関しない。 今後腎疾患における腎予備能が意義をもつためには， 経時的な腎予備能と腎機能の観察が必要である.

\section{V. おわりに}

系球体の機能に関する現在の知識をまとめ, 腎予備 能の概念と実際を述べた。腎予備能の評価方法が，本 来の意味での“reserve”を測定する検査方法として将 来にわたって生さ残る方法であるか否かに関しては, 今のところ，全く答えることが出来ない，良い検査方 法である条件としては，一定の操作方法が確立されて いること，検査によってどこの場所の，何の現象を見 ているかが明確であること, それらの結果として，個 体間, 群間の比較・検討が容易であることが挙げられ る. 残念ながら, 腎予備能に関しては, 現在のところ いずれの条件も満たしていない。

蛋白・アミノ酸の負荷により糸球体に過㮃濾過がお きるという現象は, 以前から指摘はされていたものの,
1980年代に入ってから再び注目を集めて来ているわけ であり, 疾患との関係づけに至っては，1980年代後半 からであり，極めて新しい概念と言える。この過劋滤 過が，糸球体レベルでのどのような機序により生じ， 調整されているのかを解明すると同時に, 我々臨床医 としては，模索しながらも臨床応用をいかに進めてい くかが課題になると思われる.

\section{文献}

1) Rose, B.D. : Clinical Physiology of Acid-Base and Electrolyte Disorders, 2nd. ed., p. 54, McGraw-Hill Book Company, New York, 1984.

2）高香利一, 潮木保幸: 系球沪過機序とその調節. 臨 床生理学シリーズ, 4 , 腎臓, 南江堂, 東京, 1989.

3) Tisher, C.C. and Madsen, K.M.: Anatomy of the Kidney, The Kidney 3rd ed., W.B. Saunders Co., Philadelphia, 1986.

4) Brenner, B.M., Zatz, R. and Ichikawa, I. : The Renal Circulations, The Kidney, 3rd ed., W.B. Saunders Co., Philadelphia, 1986.

5) Schmidt-Nielsen, B. and O'Dell, R.: Structure and concentrating mechanism in the mam. malian kidney. Am. J. Physiol., 200, 1119-1124, 1961.

6) Brenner, B.M., Dworkin, L.D. and Ichikawa, I.: Glomerular Filtration, The Kidney, 3rd ed., W. B. Saunders Co., Philadelphia, 1986.

7) Savin, V.J. and Terreros, D.A.: Filtration in single isolated mammalian glomeruli. Kidney 
Int., 20, 188-197, 1981.

8) Steinhausen, M., Zinnerhackl, B., Thederan, H., Dussel, R., Parekh, N., Eblinger, H., von Hagens, C., Konitowski, D. and Dallenbach, F. D. : Intraglomerular microcirculation: Measurements of single glomerular loop flow in rats. Kidney Int., 20, 230-239, 1981.

9) Brenner, B.M., Troy, J.L. and Daugharty, T.M. : The dynamics of glomerular ultrafiltration in the rat. J. Clin. Invest., 50, 1776-1780, 1971.

10) Brenner, B.M., Ueki, I.F. and Daugharty, T.M. : On estimating colloid osmotic pressure in preand postglomerular plasma in the rat. Kidney Int., 2, 51-53, 1972.

11) Pelayo, J.C., Ziegler, M.G., Jose, P.A. and Blantz, R.C.: Renal denervation in the rat: Analysis of glomerular and proximal tubular function. Am. J. Physiol., 244, F70-77, 1983.

12) Odgen, D.A.: Donor and recipient function 2 to 4 years after renal homotoransplantation. Ann. Int. Med., 67, 998-1005, 1967.

13) Deen, W.M., Maddox, D.A., Robertson, C.R. and Brenner, M.B.: Dynamics of glomerular ultrafiltration in the rat. VII. Response to reduced renal mass. Am. J. Physiol., 277, 556-562, 1974.

14) Hostetter, T.H., Olson, J.L., Rennke, H.G., Venkatachalam, M.A. and Brenner, B.M.: Hyperfiltration in remnant nephrons: A potentially adverse response to renal ablation. Am. J Physiol., 241, F85-F93, 1981.

15) Murray, B.M. and Brown, G.P.: Effect of protein intake on the autoregulation of renal blood flow. Am. J. Physiol., 258, F168-F174, 1990.

16) Ofstad, J. and Aukland, K. : Renal Circulation, The Kidney : Physiology and Pathophysiology, Seldin and Giebiseh ed., Raven Press, New York, 1985.

17) Thurau, K.: Renal hemodynamics. Am. J. Med., 36, 698-719, 1964.

18) Thurau, K. und Schnermann, J.: Die Natriumkonzentration an den Maculadensa-Zellen als regulierender Faktor für das Glomerulumfiltrat (Mikropunktions versuche). Klin. Wschr., 43, 410-416, 1965.

19) Schnermann, J., Wright, F.S., Davis, J.M., Stockelberg, W. and Grill, G. : Regulation of superficial nephron filtration rate by tubuloglomerular feedback. Pflügers Arch., 318, 147-175, 1970.

20) Schnermann, J., Ploth, P.W. and Hermle, M.:
Activation of tubulo-glomerular feedback by chloride transport. Pflügers Arch., 362, 229-240, 1976.

21) Briggs, J.P., Schnermann, J. and Wright, F.: Failure of tubule fluid osmolarity to affect feedback regulation of glomerular filtration. Am. J. Physiol., 239, F427-F432, 1980.

22) Wright, F.S. and Schnermann, J.: Interference with feedback control of glomerular filtration rate by furosemide, triflocin and cyanide. J. Clin. Invest., 53, 1695-1706, 1974.

23) Ichikawa, I.: Direct analysis of the effector mechanism of the tubuloglomerular feedback system. Am. J. Physiol., 243, F447-F455, 1982.

24) Persson, B.E. and Marsh, D.E.: GFR regulation and flow dependent electrophysiology of early distal tubule in Amphiuma. Am,. J. Physiol., 253, F263-F268, 1987.

25) Persson, B.E., Sakai, T. and Marsh, D.J. : Juxtamedullary interstitial hypertonicity in Amphiuma. Am. J. Physiol., 254, F455-F450, 1988.

26) Schnermann, J. and Briggs, J. : Concentration dependent sodium chloride transport as the signal in feed back control of glomerular filtration. Kidney Int., 22, S82-S89, 1982.

27) Taugner, R., Schiller, A., Kaissling, B. and Kritz, W.: Gap junctional coupling between the JGA and the glomerular tuft. Cell Tissue Res., 186, 279-285, 1978.

28) Rich, A. and Moor, L.C.: Transport-coupling hypothesis of tubuloglomerular signal transmission. Am. J. Physiol., 257, F882-F892, 1989.

29) Barajas, L. and Muller, J.: The innervation of the juxtaglomerular apparatus and surrounding tubules. A quantitative analysis of serial section electron microscopy. J. Ultrastruct. Res., 43, 107-132, 1973.

30) Muller, J. and Barajas, L.: Electron microscopic and histochemical evidence for tubular innervation in the renal cortex of the monkey. J. Ultrastruct. Res., 41, 533-549, 1972.

31) Dworkin, L.D. and Brenner, B.M.: Biophysical basis of glomerular filtration. The Kidney : Physiology and Pathophysiology, Seldin, D.W. and Giebisch, G., ed., Raven Press, New Yoek, 1985.

32) Ausiello, D.A., Kreisbergs, J., Roy, C. and Karnovsky, M.J.: Contraction of cultured rat glomerular mesangial cells after stimulation with angiotensin II and arginine vasopressin. J. Clin. Invest., 65, 754-760, 1980.

33) Wiseman, M.J., Hunt, R., Goodwin, A., Gross, J. 
L., Keen, H. and Viberti, G. : Dietary composition and renal function in healthy subjects. Nephron, 46, 37-42, 1987.

34) Bosch, J.P., Saccaggi, A., Lauer, A., Ronco, C., Belledonne, M. and Glabman, S. : Renal functional reserve in humans: Effect of protein intake on glomerular filtration rate. Am. J. Med., 75, 943-950, 1983.

35) Brenner, B.M., Meyer, T.W. and Hostetter, T. H. : Dietary protein intake and the progressive nature of kidney disease. The role of hemodynamically mediated glomerular injury in the pathogenesis of progressive glomerular sclerosis in aging, renal ablation, and intrinsic renal disease. N. Engl. J. Med., 307, 652-659, 1982.

36) Brenner, B.M.: Nephron adaptation to renal injury or ablation. Am. J. Physiol., 249, F324-F337, 1985.

37) Brenner, B.M.: Hemodynamically mediated glomerular injury and the progressive nature of kidney disease. Kidney Int., 23, 647-655, 1983.

38) Ihle, B.U., Becker, G.J., Whitworth, J.A., Charlwood, R.A. and Kincaid-Smith, P.S.: The effect of protein restriction on the progression of renal insufficiency. N. Engl. J. Med., 321, 1773-1774, 1989.

39) Nath, K.A., Kren, S.M. and Hostetter, T.H.: Dietary protein restriction in established renal injury in the rat. Selective role of glomerular capillary pressure in progressive glomerular dysfunction. J. Clin. Invest., 78, 1199-1205, 1986.

40) Yoshida, Y., Fogo, A., Shiraga, H., Glick, A.D., and Ichikawa, I. : Serial micropuncture analy. sis of single nephron function in subtotal renal ablation. Kidney Int., 33, 855-867, 1988.

41) Hostetter, T.H.: Human renal response to a meat meal. Am. J. Physiol., 250, F613-F618, 1986.

42) Bosch, J.P., Lauer, A. and Glabman, S. : Short-term protein loading in assessment of patients with renal disease. Am. J. Med., 77, 873-879, 1984.

43) Jones, G., Lee, K. and Swaminathan, R.: Glomerular filtration response to acute protein load. Lancet ii, 838, 1985.

44) Rodriguez-Iturbe, B., Herrena, J. and Garcia, R.: Response to acute protein load in kidney donors and in apparently normal postacute glomerulonephritis patients: Evidence for glomerular hyperfiltration. Lancet, ii, 461-464,
1985.

45) Bosch, J.P., Lews, S., Glabman, S. and Lauer, A.: Renal hemodynamic changes in humans. Response to protein loading in normal and diseased kidneys. Am. J. Med., 81, 809-815, 1986.

46) Dhaene, M., Sabot, J., Philippart, Y., Doutrelepont, J. and Vanherweghem, J.: Effects of acute protein loads of different sources on glomerular filtration. Kidney Int., 32, S25-S28, 1987.

47) Mizuiri, S., Hayashi, I., Ozawa, T., Hirata, K., Takano, M. and Sasaki, Y.: Effects of an oral protein load on glomerular filtration rate in healthy controls and nephrotic patients. $\mathrm{Ne}$ phron, 48, 101-106, 1988.

48) Laville, M., Hadi-Aissa, A., Pozet, N., LeBras, J., Labeeuw, M. and Zech, P.: Restrictions on use of creatinine clearance for measurement of renal functional reserve. Nephron, 51, 233-236, 1989.

49) Bilo, H.J.G., Schaap, G.H., Blaak, E., Gans, R.O. B., Oe, P.L. and Donker, A.J.M.: Effects of chronic and acute protein administration on renal function in patients with chronic renal insufficiency. Nephron, 53, 181-187, 1989.

50) Wetzels, J.F.M., Hoitsma, A.J., Berden, J.H.M. and Koene, R.A.P.: Renal hemodynamic effects of a short-term high protein and low protein diet in patients with renal disease. Clin. Nephrol., 30, 42-47, 1988.

51) Viberti, G., Bognetti, E., Wiseman, M.J., Dodds, R., Gross, J.L. and Keen, H.: Effect of protein-restricted diet on renal response to a meat meal in humans. Am. J. Physiol., 253, F388-F393, 1987.

52) Bergstrom, J., Ahlberg, M. and Alvestrand, A.: Influence of protein intake on renal hemodynamics and plasma hormone concentra. tions in normal subjects. Acta. Med. Scand., 217, 189-196, 1985.

53) Mansy, H., Tapson, J.S., Fernandez, J., Tapster, S. and Wilkinson, R.: Glomerular filtration response to acute protein load. Lancet, ii, 1360 , 1985.

54) Mayersohn, M., Conrad, K.A. and Achari, R. : The influence of a cooked meat meal on creatinine plasma concentration and creatinine clearance. Brit. J. Clin. Pharmacol., 15, 227-230, 1983.

55) Schuster, V.L. and Seldin, D.W.: Renal Clearance. The Kidney: Physiology and Patho. 
physiology. Seldin, D.W., and Giebisch, G., ed., Raven Press, New Yaork, 1985.

56) Ichikawa, I., Purkerson, M.L., Klahr, S., Troy, J.L., Martinez-Maldonado, M. and Brenner, B. M. : Mechanism of reduced glomerular filtration rate in chronic malnutrition. J. Clin. Invest., 65, 982-988, 1980.

57) Chan, A.Y.M., Cheng, M.L., Keil, L.C. and Meyers, B.D.: Functional response of healthy and diseased glomeruli to a large, protein-rich meal. J. Clin. Invest., 81, 245-254, 1988.

58) Baines, A.D., Ho, P. and James, H.: Metabolic control of renal vascular resistance and glomerulotubular balance. Kidney Int., 27, 848-854, 1985.

59) Lee, K.E. and Summerill, R.A.: Glomerular filtration rate following administration of individual amino acids in conscious dogs. Q.J. Exp. Physiol., 67, 459-465, 1982.

60) Palmore, W.P.: Glucagon and alanine-induced increases of the canine renal glomerular filtration rate. Q.J. Exp. Physiol., 68, 319-327, 1983.

61) Graf, H., Stummvoll, H.K., Luger, A. and Proger, R.: Effect of amino acid infusion on glomerular filtration rate. N. Engl. J. Med., 308, 159-160, 1983.

62) ter Wee, P.M., Rosman, J.B., van der Geest, S., Sluiter, W.J. and Donker, J.M.: Renal hemodynamics during separate and combined infusion of amino acids and dopamine. Kidney Int., 29, 870-874, 1986.

63) Castellino, P., Coda, B. and De Fronzo, R.: Effect of amino acid infusion on renal hemodynamics in humans. Am. J. Physiol., 251, F132-F140, 1986.

64) Castellino, P., Hunt, W. and De Fronzo, R.A.: Regulation of renal hemodynamics by plasma amino acid and hormone concentrations. Kidney Int., 32, S15-S20, 1987.

65) Ruilope, L.M., Rodicio, J., Robles, R.G., Sancho, J., Miranda, B., Granger, J.P. and Romero, J.C. : Influence of a low sodium diet on the renal response to amino acid infusions in humans. Kidney Int., 31, 992-999, 1987.

66) Castellino, P., Giordano, C., Perna, A. and De Fronzo, R.A.: Effects of plasma amino acid and hormone levels on renal hemodynamics in humans. Am. J. Physiol., 255, F444-F449, 1988.

67) Hirschberg, R. and Kopple, J.D.: Role of growth hormone in the amino acid-induced acute rise in renal function in man. Kidney Int., 32, 382-387, 1987.
68) Hirschberg, R., Zipser, R.D., Solomowitz, L.A. and Kopple, J.O. :Glucagon and prostaglandins are mediators of amino acid-induced rise in renal hemodynamics. Kidney Int., 33 , 1147-1155, 1988.

69) Waterhouse, C., Clarke, E.F., Heining, R.E., Lewis, A.M. and Jeanpreter, N.: Free amino acid levels in the blood of patients undergoing parenteral alimentation. Am. J. Clin. Nutr., 32, 2423-2429, 1979.

70) Breizis, M., Silvia, P. and Epstein, F.: Amino acid (AA) induce renal vasodilatation in the isolated perfused kidney: Coupling oxidative metabolism (Abstract). Kidney Int., 25, 286a, 1984.

71) Seney, F.D. and Wright, F.S. : Dietary protein suppresses feedback control of glomerular filtration in rats. J. Clin. Invest., 75, 558-568, 1985.

72) Premen, A.J.: Importance of the liver during glucagon-mediated increases in canine renal hemodynamics. Am. J. Physiol., 249, F319-F322, 1985.

73) Fioretto, P., Trevisan, R., Valerio, A., Avogaro, A., Borsato, M., Doria, A., Semplicini, A., Sacerdoti, D., Jones, S., Bognetti, E., Viberti, G.C. and Nosadini, R.: Impaired renal response to a meat meal in insulin-dependent diabetes: Role of glucagon and prostaglandins. Am. J. Physiol., 258, F675-F683, 1990.

74) Pullman, R.N., Havender, A.R. and Aho, I.: Direct effects of glucagon on renal hemodynamics and excretion of inorganic ions. Metabolism, 16, 358-373, 1967.

75) Levy, M.: The effect of glucagon on glomerular filtration rate in dogs during reduction of renal blood flow. Can. J. Physiol. Pharmacol., 53, 660-665, 1975.

76) Parving, H., Noer, J., Kehlet, H., Mogensen, C. E., Sevendsen, P.A. and Heding, L. : The effect of short-term glucagon infusion on kidney function in normal man. Diabetologia, 13, 323-325, 1977.

77) Premen, A.J., Hall, J.E. and Smith, M.J. : Postprandial regulation of renal hemodynamics: Role of pancreatic glucagon. Am. J. Physiol., 248, F656-F662, 1985.

78) Dratwa, M., Burette, A., van Gossum, M., Collart, F., Wens, R., Charier, L., Tielmans, C. and Peltenre, M. : No rise in glomerular filtration rate after protein loading in cirrhotics. Kidney Int., 32, S32-S34, 1987. 
79) Uranga, J.: Some characteristics of hepatic glomerular pressure substance. Am. J. Physiol., 220, 1617-1620, 1971.

80) Uranga, J., Fuenzalida, R., Rapoport, A.L. and Castillo, E.: Effect of glucagon and glomerulopressin on the renal function of the dog. Horm. Metab. Res., 11, 275-279, 1979.

81) Corvilain, J. and Abramow, M.: Some effects of human growth hormone on renal hemodynamics and on tubular phosphate transport in man. J. Clin. Invest., 41, 1230-1235, 1962.

82) Haffner, D., Ritz, E., Mehls, O., Rosman, J., Blum, W., Heinrich, U. and Hubinger, A.: Growth hormone induced rise in glomerular filtration rate is not obliterated by angiotensinconverting enzyme inhibitors. Nephron, 55, 63-68, 1990.

83) Stahl, R.A.K., Kudelka, S. and Helmchen, U.: High protein intake stimulates glomerular prostaglandin formation in remnant kidneys. Am. J. Physiol., 252, F1083-F1094, 1987.

84) Vanrenterghem, Y.F.C., Verbercknoes, R.K.A., Roels, L.M. and Michielsen, P.J. : Role of prostaglandins in protein-induced glomerular hyperfiltration in normal humans. Am. J. Physiol., 254, F463-F469, 1988.

85) Paller, M.S. and Hostetter, T.H.: Dietary protein increases plasma renin and reduces pressor reactivity to angiotensin II. Am. J. Physiol., 251, F34-F39, 1986.

86) Bolin, P., Jaffa, A.A., Rust, P.F. and Mayfield, R.K.: Acute and chronic responses of human renal kallikrein and kinins to dietary protein. Am. J. Physiol., 257, F718-F723, 1989.

87) Beukhof, H.R., ter Wee, P.M., Sluiter, W.J. and
Donker, A.T.M. : Effect of low-dose dopamine on effective renal plasma flow and glomerular filtration rate in 32 patients with IgA glomerulopathy. Am. J. Nephrol., 5, 267-270, 1985.

88) ter Wee, P.M., Smit, A.J., Rosman, J.B., Sluiter, W.J. and Donker, A.J.M.: Effect of intravenous infusion of low-dose dopamine on renal function in normal individuals and in patients with renal disease. Am. J. Nephrol., 6, 42-46, 1986.

89）服部元史, 川口 洋, 甲斐深雪, 永田道子, 長田道 夫, 伊藤克己：小児各種堅炎患者に打ける dopamine 負荷試験による堅予備能の検討，日児 誌, 91，3017-3023， 1987.

90) Dhane, M., Sabot, J., Philippart, Y., Doutrelepont, J., Vanherweghem, J. and Toussaint, C. : Renal functional reserve of transplanted kidneys. Nephron, 44, 157-158, 1986.

91）服部元史，伊藤克己，甲斐潹雪，川口 洋，山口 裕, 長右道夫, 永田道子, 小松康宏, 武田優美子, 高橋公太, 寺岡 慧, 東間 紘, 太田和夫：小児腎 移植患者における dopamine 負荷試験による移植 堅機能評価について。移植，23，253-258，1988.

92) Cairns, H.S., Raval, U. and Neild, G.H.: Failure of cyclosporine-treated renal allograft recipients to increase glomerular filtration rate following an amino acid infusion. Transplantation, 46, 79-82, 1988.

93) Zuccala; A., Zucchelli, G.A. and Zucchelli, P.: Renal functional reserve in patients with a reduced number of functioning glomeruli. Clin. Nephrol., 32, 229-234, 1989.

94) Castiglioni, A. and Savazzi, G.M.: Physiology and clinical aspects of diabetic nephropathy. Nephron, 50, 151-163, 1983. 